\title{
PENERAPAN SISTEM REKRUTMEN UNTUK MENINGKATKAN KETERIKATAN KARYAWAN
}

\author{
Dematria Pringgabayu \\ Hendriady de Keizer
}

Politeknik Pajajaran ICB Bandung, Indonesia

Email: demabayu5@gmail.com

Submitted: Dec 22, 2016; Reviewed: Dec 24, 2016; Accepted: Mar 10, 2017

\begin{abstract}
High employee engagement can have a positive effect on the progress of a company's business, including one of them is an insurance company. One of the factors that can shape employee attachment, whether it increases employee engagement, even lowers it, is the existing recruitment system in the company concerned. When an employee is recruited, starting from the first call-up session, until the employee enters the first day of work, the employee must pass through a series of recruitment systems. This research is conducted with the intention to test and know the factors that can increase employee's attachment one of which consists of recruitment system, and also by using work environment as moderation variable. The results show that employee selection and job design have a direct influence in establishing employee engagement, while the new employee orientation will increase employee engagement if moderated or reinforced by the environmental factors in which they work, and has no direct effect on increasing employee engagement.
\end{abstract}

Keywords: employee engagement; health insurance company ; recruitment system; work environment

\section{PENDAHULUAN}

Sumber daya manusia merupakan aset penting bagi perusahaan karena manusia merupakan sumber daya yang dinamis dan harus dimiliki oleh perusahaan dalam mencapai tujuannya, oleh sebab itu karyawan harus dimanfaatkan semaksimal mungkin untuk mencapai tujuan yang telah ditetapkan. Agar tujuan perusahaan dapat tercapai, maka karyawan-karyawan yang ada di dalamnya harus memiliki engagement yang baik agar karyawan merasa perduli akan masa depan dari perusahaan tempatnya bekerja dan bersedia untuk memberikan sejumlah usaha dan kemampuan yang dimilikinya untuk melihat kesuksesan perusahaan tempatnya bekerja.

Begitu juga di dalam sebuah perusahaan asuransi milik swasta, sumber daya manusia memegang peranan yang penting untuk menjaga kelangsungan bisnis perusahaan. Semakin banyaknya jumlah nasabah asuransi kesehatan, tentunya sangat berpengaruh positif bagi perusahaan asuransi kesehatan, namun hal tersebut juga harus diimbangi oleh sumber daya manusia milik perusahaan, terutama pada bagian operasional asuransi kesehatan khususnya departemen claim health provider yang tentunya harus bisa memberikan pelayanan secara maksimal kepada para nasabah agar mereka merasa puas terhadap perusahaan dan menunjukkan loyalitasnya. Namun demikian, jika dikaji lebih lanjut, disinilah terlihat muncul permasalahan dari segi internal,di mana berdasarkan data yang didapatkan oleh penulis, bahwa dari tahun 2014 sampai dengan tahun 2015 lalu, jumlah karyawan yang ada di departemen claim health provider memiliki persentase rata-rata pengunduran diri lebih dari $50 \%$, bahkan di perusahaan asuransi swasta cabang Bandung tingkat pengunduran diri karyawan baru mencapai $80 \%$. Kemudian pada tahun 2015 pun departemen claim health provider ternyata masih saja mengalami permasalahan yang serupa, di mana persentase pengunduran diri secara keseluruhan jika dirataratakan berada di atas $60 \%$ selama dua tahun terakhir.

Berkaitan dengan fenomena tingginya tingkat pengunduran diri karyawan departemen claim health provider yang sejak tahun 2014 dan 2015 memiliki rata-rata lebih dari 60\%, menurut 
asumsi penulis merupakan gejala dari rendahnya tingkat employee engagement karyawan perusahaan asuransi swasta terutama di departemen claim health provider. Asumsi penulis tersebut diperkuat oleh hasil penelitian yang dilakukan oleh Albdour \& Altarawneh (2014) yang membuktikan bahwa pengunduran diri karyawan dari sebuah perusahaan, merupakan sebuah indikasi kuat bahwa karyawan tersebut tidak memiliki komitmen yang tinggi terhadap perusahaan, yang disebabkan oleh rendahnya employee engagement (keterikatan karyawan) yang dimiliki karyawan, dalam hal ini adalah karyawan departemen claim health provider.

Markos \& Sridevi (2010) pun menjelaskan bahwa ketika seorang karyawan merasa terikat pada perusahaan tempatnya bekerja, ia tidak hanya menjadi loyal seberapa berat pun pekerjaan yang harus dijalaninya, tapi karyawan itu akan merasa peduli dan memiliki, serta merasa menjadi bagian penting dalam perusahaan. Mereka pun akan menunjukkan sebuah hubungan yang aktif dengan perusahaannya di mana karyawan bersedia untuk memberikan sesuatu dari diri mereka untuk membantu keberhasilan dan kemakmuran perusahaan.

Jika kondisi seperti ini - keterikatan karyawan rendah - tidak segera dibenahi sesegera mungkin oleh pihak perusahaan asuransi, maka bukan tidak mungkin kinerja departemen claim health provider secara keseluruhan akan terganggu, dan bisa berdampak pada kekecewaan nasabah-nasabah asuransi kesehatan yang mengajukan klaim. Karyawan yang mengundurkan diri akan menyebabkan jumlah sumber daya manusia menjadi berkurang, sedangkan jumlah klaim bisa meningkat, sehingga berdampak pada tidak selesainya klaim-klaim asuransi kesehatan yang terus menumpuk setiap harinya. Bahkan dalam jangka panjang, reputasi perusahaan asuransi swasta terutama untuk produk asuransi kesehatannya menjadi terancam.

Secara keseluruhan, bisa dikatakan bahwa permasalahan utama yang saat ini dialami oleh perusahaan asuransi swasta terutama di departemen claim health provider adalah rendahnya keterikatan karyawan, yang dapat terlihat dari kurang adanya rasa "memiliki" terhadap perusahaan, sehingga karyawan bekerja hanya sekedar bekerja tanpa ada keinginan untuk mengembangkan perusahaan tempatnya bekerja. Hal ini dipertegas pula oleh pendapat dari 168
Baumruk dan Gorman (2006) yaitu pada saat karyawan memiliki rasa keterkaitan (engage) yang tinggi dengan perusahaan, maka karyawan akan meningkatkan perilakunya secara umum, salah satunya yaitu stay (tetap tinggal) atau dengan kata lain karyawan akan tetap bekerja di perusahaan walaupun ada peluang untuk bekerja di tempat lain.

Penulis melihat ada sebuah fenomena menarik, di mana pada satu sisi perusahaan asuransi swasta ini berhasil berkembang menjadi sebesar sekarang, dengan tingkat keuntungan (profit) yang tinggi serta berhasil meraih berbagai penghargaan terhormat, namun di sisi lain yaitu dari internal perusahaan, karyawan ternyata memiliki permasalahan dalam hal keterikatan karyawan terutama di departemen claim health provider.

Salah satu faktor yang dapat membentuk keterikatan karyawan, baik itu meningkatkan keterikatan karyawan, bahkan menurunkannya, adalah sistem rekrutmen yang ada di perusahaan yang bersangkutan. Pada saat karyawan direkrut, mulai dari sesi pemanggilan pertama kali, hingga karyawan tersebut masuk di hari pertamanya bekerja, karyawan harus melewati serangkaian sistem rekrutmen yang sudah ditetapkan oleh perusahaan. Dalam rangkaian tersebut, karyawan diberitahukan berbagai informasi dan persyaratan untuk diterima menjadi karyawan, dan apabila rekrutmen tidak dilakukan secara efektif (jangka waktu dan prosedur yang tepat), maka karyawankaryawan yang direkrut pun akan lebih cepat merasa bahwa dirinya tidak cocok bekerja di perusahaan tersebut, dan mengundurkan diri hanya dalam jangka waktu yang singkat. (Kaliannan \& Adjovu, 2014; Crocket, 2009)

Namun Rana et al. (2014) dalam penelitiannya membuktikan bahwa lingkungan kerja merupakan variabel yang paling berkaitan dengan pemenuhan kebutuhan dan perasaan karyawan, serta menyediakan feedback yang positif bagi karyawan agar bisa menunjukkan perhatian kepada perusahaan. Sehingga kondisi lingkungan kerja juga bisa memperkuat atau bahkan memperlemah keterikatan karyawan di perusahaan.

Oleh karena itu penelitian ini bertujuan untuk menganalisis lebih lanjut, dimensi-dimensi apa saja dalam sistem rekrutmen yang dianggap paling mampu untuk meningkatkan keterikatan karyawan di perusahaan, khususnya di departemen claim health provider. 


\section{IDENTIFIKASI MASALAH}

Berdasarkan uraian tersebut, penelitian dilakukan dengan maksud untuk menguji dan mengetahui faktor-faktor yang membentuk keterikatan karyawan yang terdiri dari sistem rekrutmen, dengan lingkungan kerja sebagai variabel moderasi. Permasalahan yang diteliti selanjutnya dirumuskan sebagai berikut :

1. Dimensi sistem rekrutmen yang secara langsung dapat berpengaruh terhadap keterikatan karyawan departemen claim health provider

2. Sebesar apa pengaruh dimensi-dimensi sistem rekrutmen setelah dimoderasi oleh lingkungan kerja terhadap keterikatan karyawan departemen claim health provider

3. Apakah terdapat pengaruh sistem rekrutmen secara simultan yang dimoderasi oleh variabel lingkungan kerja?

\section{TINJAUAN PUSTAKA \\ Keterikatan Karyawan}

Keterikatan karyawan (employee engagement) mengacu pada kondisi perasaan, dan pemikiran yang sungguh-sungguh dan konsisten yang tidak hanya berfokus pada objek, peristiwa individu atau perilaku tertentu. Keterikatan karyawan merupakan sikap positif karyawan disertai dengan motivasi baik secara kognitif dan penghayatan, yakin akan kemampuan dan merasa senang saat bekerja. Employee Engagement merupakan antusiasme karyawan dalam bekerja, yang terjadi karena karyawan mengarahkan energinya untuk bekerja, yang selaras dengan prioritas strategic perusahaan. Antusiasme ini terbentuk karena karyawan merasa engage (feel engaged) sehingga berpotensi untuk menampilkan perilaku yang engaged. Perilaku yang engage memberikan dampak positif bagi organisasi yaitu peningkatan revenue (Indrianti, 2012).

Schaufeli dan Bakker (dalam Indrianti, 2012) menyatakan bahwa keterikatan kerja pada dasarnya dipengaruhi oleh dua hal, yaitu model JDR (job demand-resources) dan modal psikologis (psychological capital). Modal JD-R meliputi beberapa aspek seperti lingkungan fisik, sosial dan organisasi, gaji, peluang untuk berkarir, dukungan supervisor, dan rekan kerja. Sedangkan modal psikologis meliputi kepercayaan diri rasa optimis, harapan mengenai masa depan, serta resiliensi. Employee Engagement sebagai penghayatan seorang karyawan terhadap tujuan dan pemusatan energi, yang muncul dalam bentuk inisiatif, adaptibilitas, usaha, dan kegigihan yang mengarah kepada tujuan organisasi. Keterikatan kerja terjadi ketika seorang karyawan memiliki perasaan positif dengan pekerjaannya, bersedia terlibat dan mencurahkan energinya demi tercapainya tujuantujuan perusahaan, menghayati pekerjaan yang dilakukan dengan disertai antusiame. (Macey et al., 2009: Setiadi, 2014)

Menurut Macey et al. (2009) Employee Engagement mencakup 2 dimensi penting, yaitu:

1. Employee Engagement sebagai energi psikis Karyawan merasakan pengalaman puncak (peak experience) dengan berada di dalam pekerjaan dan arus yang terdapat di dalam pekerjaan tersebut. Employee Engagement merupakan keseriusan ketika larut dalam pekerjaan (immersion), perjuangan dalam pekerjaan (striving), penyerapan (absorption), fokus (focus) dan juga keterlibatan (involvement).

2. Employee Engagement sebagai energi tingkah laku: Bagaimana Employee Engagement terlihat oleh orang lain. Employee Engagement terlihat oleh orang lain dalam bentuk tingkah laku yang berupa hasil. Tingkah laku yang terlihat dalam pekerjaan berupa:

a. Karyawan akan berfikir dan bekerja secara proaktif, akan mengantisipasi kesempatan untuk mengambil tindakan dan akan mengambil tindakan dengan cara yang sesuai dengan tujuan organisasi.

b. Karyawan yang engaged tidak terikat pada "job description", mereka fokus pada tujuan dan mencoba untuk mencapai secara konsisten mengenai kesuksesan organisasi.

c. Karyawan secara aktif mencari jalan untuk dapat memperluas kemampuan yang dimiliki dengan jalan yang sesuai dengan visi dan misi perusahaan.

d. Karyawan pantang menyerah walau dihadapkan dengan rintangan atau situasi yang membingungkan.

Sedangkan menurut Watson (dalam Rana et al, 2014) keteterikatan karyawan mengacu pada hubungan yang luas dan mendalam antara orang dan organisasi. Keterikatan memainkan peran penting dalam lingkungan bisnis. Dapat didefinisikan, keterikatan karyawan meliputi 3 dimensi yaitu :

1. Rational: Karyawan memahami dengan baik peran dan tanggung jawab mereka. 
2. Emotional: Seberapa banyak gairah/antusias mereka untuk bekerja dan antusias terhadap organisasi mereka

3. Motivational: Mereka bersedia berkontribusi dengan berusaha dan bekerja sesuai peran mereka masing-masing dengan baik

\section{Lingkungan Kerja}

Kehidupan manusia tidak terlepas dari berbagai keadaan lingkungan sekitarnya, antara manusia dan lingkungan terdapat hubungan yang sangat erat. Dalam hal ini, manusia akan selalu berusaha untuk beradaptasi dengan berbagai keadaan lingkungan sekitarnya. Demikian pula halnya ketika melakukan pekerjaan, karyawan sebagai manusia tidak dapat dipisahkan dari berbagai keadaan di sekitar tempat mereka bekerja, yaitu lingkungan kerja. Selama melakukan pekerjaan, setiap karyawan akan berinteraksi dengan berbagai kondisi yang terdapat dalam lingkungan kerja. Berikut adalah beberapa definisi lingkungan kerja yang dikemukakan oleh beberapa ahli :

Komarudin (2007:231), menyatakan bahwa :

"Lingkungan kerja adalah kehidupan sosial, psikologi, dan fisik dalam perusahaan yang berpengaruh terhadap pekerja dalam melaksanakan tugasnya”.

Kehidupan sosial yang dimaksud berkenaan dengan keyakinan nilai-nilai, sikap, pandangan, pola atau gaya hidup di lingkungan sekitar serta interaksi antara orang-orang yang bekerja dalam suatu perusahaan baik itu interaksi antara atasan dengan bawahan maupun dengan rekan kerja. Kehidupan psikologis adalah interaksi perilaku-perilaku karyawan dalam suatu perusahaan dimana mereka bekerja. Setiap orang dalam suatu perusahaan membawa suatu harapan akan pemenuhan kebutuhan dan keinginan. Adanya kebutuhan dan keinginan itu mendorong mereka berperilaku untuk memuaskan kebutuhan dan keinginannya. Kehidupan fisik adalah interaksi antara karyawan dengan lingkungan tempat karyawan bekerja.

Mangkunegara (2009:105), menyatakan bahwa : "Lingkungan kerja adalah semua aspek fisik kerja, psikologis kerja dan peraturan kerja yang dapat mempengaruhi kepuasan kerja, motivasi dan pencapaian produktivitas". Selain itu Sedarmayanti (2011:11) menyatakan bahwa : "Lingkungan kerja adalah keseluruhan alat perkakas dan bahan yang dihadapi lingkungan sekitarnya di mana seseorang bekerja, metode kerjanya, serta pengaturan kerjanya baik sebagai perseorangan maupun sebagai kelompok”.

Berdasarkan uraian definisi-definisi yang dikemukakan oleh para ahli, maka dapat dilihat bahwa lingkungan kerja mempunyai peranan nyata dalam suatu kehidupan kerja manusia. Peranan lingkungan kerja yang baik adalah sebagai pendorong bagi karyawan sehingga mereka merasa nyaman dalam melakukan pekerjaannya, dapat lebih bersemangat, dan pada akhirnya dapat bekerja secara optimal, sehingga tidak dapat dipungkiri bahwa lingkungan kerja dalam suatu perusahaan mendapatkan perhatian yang lebih jauh lagi dibandingkan pada waktuwaktu terdahulu. Hal ini dapat terjadi karena seiring meningkatnya standar hidup seseorang, maka ia akan cenderung menginginkan suasana yang memberikan dukungan dalam melaksanakan pekerjaannya.

\section{Sistem Rekrutmen}

Rekrutmen adalah putusan sumber daya manusia (SDM) berupa banyak dibutuhkan, kapan dibutuhkan, serta pengetahuan, keterampilan, kemampuan khusus yang dimiliki. Penarikan (rekrutmen) pegawai merupakan suatu proses atau tindakan yang dilakukan oleh organisasi untuk mendapatkan tambahan pegawai melalui beberapa tahapan mencakup identifikasi dan evaluasi sumber-sumber penarikan tenaga kerja, menentukan kebutuhan tenaga kerja, proses seleksi, penempatan, dan orientasi tenaga kerja.

Penarikan pegawai bertujuan menyediakan pegawai yang cukup agar manajemen dapat memilih karyawan yang memenuhi kualifikasi yang mereka perlukan (Malthis, 2006:112). Rekrutmen merupakan proses komunikasi dua arah. Para pelamar menghendaki informasi yang akurat mengenai seperti apakah rasanya bekerja di dalam organisasi bersangkutan. Organisasiorganisasi sangat menginginkan informasi yang akurat tentang seperti apakah pelamar-pelamar tersebut jika kelak mereka diangkat sebagai pegawai.

Sementara menurut Sukirno (2004:98) rekrutmen adalah proses menarik orang-orang yang memenuhi persyaratan untuk mengajukan lamaran atas pekerjaan yang belum terisi,yang terbagi atas rekrutmen internal dan eksternal.rekrutmen internal merupakan promosi karyawan yang dalam oganisasi yang tujuannya untuk menjaga dan mempertahankan karyawan yang memiliki kinerja baik. Rekrutmen eksternal melibatkan usaha menarik orang-orang dari luar organisasi untuk mengisi lowongan pekerjaan 
melalui pemasangan iklan, wawancara pameran peluang kerja dan metode lainnya. Agar kualitas tenaga kerja yang diperoleh sesuai dengan keinginan perusahaan, maka terlebih dahulu perusahaan harus memilih sumber-sumber tenaga kerja yang tersedia.

\section{HIPOTESIS}

\section{Pengaruh Sistem Rekrutmen terhadap Keterikatan Karyawan}

Berdasarkan data-data sekunder yang sudah dipaparkan pada bab sebelumnya, penulis berpendapat ada beberapa faktor yang membentuk keterikatan karyawan departemen claim health provider diantaranya sistem rekrutmen yang kurang efektif dikarenakan proses rekrutmen tersebut tidak bisa dilakukan secara total mengingat perekrutan karyawan baru pun tidak dilakukan dalam jangka waktu tertentu. Padahal sistem rekrutmen yang merupakan bagian dari HR Practices di sebuah perusahaan, dianggap dapat membentuk keterikatan karyawan yang tinggi (Kaliannan \& Adjovu, 2014; Crocket, 2009).

Hipotesis 1: Sistem rekrutmen berpengaruh positif terhadap keterikatan karyawan

\section{Pengaruh Moderasi Lingkungan Kerja terhadap Keterikatan Karyawan}

Sedangkan lingkungan kerja dalam penelitian ini menjadi variabel moderasi, yang bisa memperkuat atau bahkan memperlemah keterikatan karyawan, seperti yang dibuktikan dalam penelitian Rana et al. (2014) bahwa lingkungan kerja berkaitan dengan pemenuhan kebutuhan dan perasaan karyawan, serta menyediakan feedback yang positif bagi karyawan agar bisa menunjukkan perhatian kepada perusahaan

Hipotesis 2: Lingkungan kerja berpengaruh positif sebagai variabel moderasi terhadap keterikatan karyawan

\section{KERANGKA PEMIKIRAN}

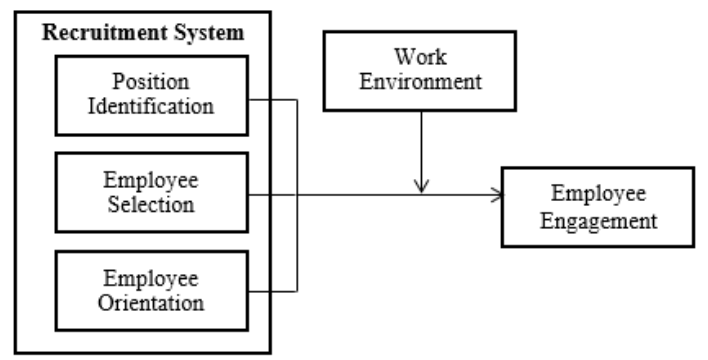

Gambar 1 Kerangka Pemikiran

\section{METODE PENELITIAN}

Penelitian yang dilakukan adalah dengan metode deskriptif verifikatif yaitu suatu bentuk penelitian yang berdasarkan data yang dikumpulkan selama penelitian secara sistematis mengenai fakta-fakta dan sifat-sifat dari obyek yang diteliti dengan menggabungkan hubungan antar variabel yang terlibat di dalamnya kemudian diinterpretasikan berdasarkan teoriteori dan literatur-literatur yang berhubungan dengan sistem rekrutmen, keterikatan karyawan serta lingkungan kerja sebagai variabel moderasi.

\section{Populasi dan Sampel}

Populasi menurut Sugiyono (2013: 90) adalah wilayah generalisasi yang terdiri atas objek/subjek yang mempunyai kualitas dan karakteristik tertentu yang ditetapkan oleh peneliti untuk dipelajari dan kemudian ditarik kesimpulannya. Populasi dalam penelitian ini adalah karyawan departemen Claim health provider, dengan jumlah sebanyak 94 orang. Metode pengambilan sampel menggunakan sensus, oleh karena itu dalam penelitian ini sampel terpilih sebanyak 94 orang karyawan departemen Claim health provider.

\section{Rancangan Uji Hipotesis}

Adapun rancangan yang dilakukan oleh penulis adalah sebagai berikut:

\section{a) Menentukan Hipotesis Statistik}

Berdasarkan pada alat statistik yang digunakan dan dihipotesis penelitian di atas maka penulis menetapkan dua hipotesis yang digunakan untuk uji statistiknya yaitu hipotesis nol $\left(\mathrm{H}_{0}\right)$ yang diformulasikan untuk ditolak dan hipotesis alternatif $\left(\mathrm{H}_{\mathrm{a}}\right)$ yaitu hipotesis penulis yang diformulasikan untuk diterima dengan perumusan sebagai berikut: 
1. Ha: Sistem rekrutmen memiliki pengaruh terhadap keterikatan karyawan

Ho: Sistem rekrutmen tidak memiliki pengaruh terhadap keterikatan karyawan

2. Ha: Sistem rekrutmen berpengaruh terhadap keterikatan karyawan setelah dimoderasi oleh variabel lingkungan kerja

Ho: Sistem rekrutmen tidak berpengaruh terhadap keterikatan karyawan setelah dimoderasi oleh variabel lingkungan kerja

b) Menetapkan Tingkat Signifikan

Dasar pengambilan keputusan berdasarkan angka signifikan menurut Tingkat signifikansi dapat ditentukan dengan melakukan pengujian terhadap dua pihak. Untuk menguji diterima atau ditolaknya hipotesis, maka dilakukan dengan cara pengujian dua pihak dengan tingkat signifikan $=5 \%$.

c) Uji Hipotesis (uji t)

Untuk mengetahui tingkat signifikansi dari koefisien korelasi, maka penulis menggunakan statistik Uji ' $t$ ' dengan rumus sebagai berikut:

$$
\begin{aligned}
& \mathrm{t}_{\text {hitung }}=\frac{r \sqrt{n-2}}{\sqrt{1-r^{2}}} \\
& \text { dimana: } \\
& \mathrm{t}=\text { hasil uji tingkat signifikansi } \\
& \mathrm{r}=\text { koefisien korelasi } \\
& \mathrm{n}=\text { jumlah data }
\end{aligned}
$$

d) Koefisien Determinasi (KD)

Koefisien determinasi $\left(\mathrm{R}^{2}\right)$ pada intinya mengukur seberapa jauh kemampuan model dalam menerangkan variasi variabel dependen. Nilai koefisien determinasi antara nol dan satu. Nilai $\left(R^{2}\right)$ yang kecil berarti kemampuan variabel-variabel independen dalam menjelaskan variasi variabel dependen amat terbatas. Nilai yang mendekati satu berarti variabel-variabel independen memberikan hampir semua informasi yang dibutuhkan untuk memprediksi variasi variabel dependen. Secara umum koefisien determinasi untuk data silang (cross section) relatif rendah karena adanya variasi yang besar antara masing-masing pengamatan, sedangkan untuk data runtut waktu (time series) biasanya mempunyai nilai koefisien determinasi yang tinggi (Ghozali, 2012).

\section{e) Menentukan Kriteria Penerimaan Hipotesis}

Agar hasil perhitungan koefisien korelasi dapat diketahui tingkat signifikan atau tidak signifikan maka hasil perhitungan dari statistik uji t (t hitung) tersebut selanjutnya dubandingkan dengan $\mathrm{t}$ tabel. Tingkat signifikannya yaitu $5 \%(\alpha=0,05)$, artinya jika hipotesis nol ditolak dengan taraf kepercayaan 95\%, maka kemungkinan bahwa hasil dari penarikan kesimpulan mempunyai kebenaran 95\% dan hal ini menunjukkan adanya hubungan (korelasi) yang meyakinkan (signifikan) antara dua variabel tersebut.

f) Analisis model regresi moderasi

Oleh karena penelitian ini menggunakan rancangan regresi moderasi, sehingga terdiri dari beberapa langkah dalam menetapkan model regresi yaitu:

1) $Y=a+b_{1} X_{1}+b_{2} X_{2}+b_{3} X_{3}$

2) $Y=a+b_{1} X_{1}+b_{2} X_{2}+b_{3} X_{3}+b_{4} X_{4}$

3) $Y=a+b_{1} X_{1}+b_{2} X_{2}+b_{3} X_{3}+b_{4} X_{4}+$ $\mathrm{b}_{5} \mathrm{X}_{4} \mathrm{X}_{1}+\mathrm{b}_{6} \mathrm{X}_{4} \mathrm{X}_{2}+\mathrm{b}_{7} \mathrm{X}_{54} \mathrm{X}_{3}$

Keterangan:

$\mathrm{Y}=$ Keterikatan Karyawan

$\mathrm{a}=$ Nilai Konstanta

b1 = Koefisien regresi untuk X1

b2 = Koefisien regresi untuk X2

b3 = Koefisien regresi untuk X3

b4 = Koefisien regresi untuk variable moderasi

$\mathrm{X} 1$ = Identifikasi posisi

X2 = Seleksi Karyawan

X3 = Orientasi karyawan

X4 = Lingkungan kerja

\section{HASIL PENELITIAN}

Analisis kuantitatif dilakukan melalui penyebaran kuesioner kepada seluruh karyawan departemen claim health provider dengan total sebanyak 94 karyawan. Kuesioner yang disebarkan terdiri atas 45 item pernyataan yang mewakili satu variabel bebas, satu variabel terikat dan satu variabel lagi sebagai moderator. Pengolahan data dilakukan menggunakan program aplikasi statistik dengan melalui beberapa tahapan regresi berganda, dan hasilnya adalah sebagai berikut.

Tabel 1 dijelaskan lebih lanjut sebagai berikut:

1. Position identification sebelum dimoderasi oleh Work Environment memiliki nilai korelasi (Beta) dengan keterikatan karyawan 
sebesar 0.230, dan setelah dimoderasi oleh Work Environment nilai Beta tersebut menurun menjadi 0.189. Dengan kata lain variabel Work Environment memperlemah hubungan antara Position identification dengan keterikatan karyawan. Hal ini memperlihatkan bahwa Position identification bukanlah variabel yang dapat dimoderasi atau diperkuat oleh kondisi Work Environment yang dirasakan oleh karyawan, sehingga dapat secara langsung memiliki dampak terhadap pembentukan keterikatan karyawan di sebuah perusahaan. Position identification yang tepat diasumsikan dapat membuat karyawan merasa terikat dengan tempatnya bekerja karena ia akan cenderung lebih cocok dan merasa nyaman dengan beban kerja sesuai dengan posisi yang ditempatinya.

2. Variabel employee selection sebelum dimoderasi oleh Work Environment memiliki nilai korelasi (Beta) dengan keterikatan karyawan sebesar 0.664, dan setelah dimoderasi oleh Work Environment nilai Beta tersebut menurun menjadi 0.608 . Dengan kata lain variabel Work Environment memperlemah hubungan antara employee selection dengan keterikatan karyawan. Hasil ini mencerminkan bahwa employee selection secara langsung akan lebih mempengaruhi keterikatan karyawan kepada perusahaan tempatnya bekerja. Employee selection yang dianggap mencukupi bagi karyawan akan membuat karyawan merasa tidak lagi perlu mencari tempat kerja yang lain

\begin{tabular}{|c|c|c|c|c|c|c|}
\hline & & & efficients ${ }^{2}$ & & & \\
\hline & & Unstan & dardized & Standardized & & \\
\hline Model & & Coeff & ficients & Coefficients & $\mathrm{T}$ & Sig. \\
\hline & & $\mathrm{B}$ & Std. Error & Beta & & \\
\hline 1 & (Constant) & 13.856 & 6.943 & & 1.996 & .049 \\
\hline & Identification & .391 & .164 & .230 & 2.381 & .019 \\
\hline & Selection & 1.009 & .312 & .664 & 3.236 & .002 \\
\hline & Orientation & .383 & .414 & .171 & .923 & .358 \\
\hline 2 & (Constant) & 14.470 & 7.101 & & 2.038 & .045 \\
\hline & Identification & .394 & .165 & .232 & 2.386 & .019 \\
\hline & Selection & .992 & .315 & .653 & 3.146 & .002 \\
\hline & Orientation & .453 & .216 & .202 & 2.093 & .039 \\
\hline & Work Environment & -.036 & .079 & -.040 & -.458 & .648 \\
\hline 3 & (Constant) & -18.608 & 79.939 & & -.233 & .817 \\
\hline & Identification & -4.241 & 2.279 & -2.497 & -1.861 & .066 \\
\hline & Selection & -1.360 & 4.087 & -.895 & -.333 & .740 \\
\hline & Orientation & 1.474 & 2.968 & .657 & .497 & .621 \\
\hline & Work Environment & 1.185 & 2.912 & 1.306 & .407 & .685 \\
\hline & $\mathrm{Id} \mathrm{d}^{*} \mathrm{LK}$ & -.035 & .109 & -1.411 & -.323 & .748 \\
\hline & Sel*LK & .084 & .150 & 3.039 & .560 & .577 \\
\hline & Ori*LK & .169 & .083 & 4.443 & 2.043 & .044 \\
\hline 4 & (Constant) & 21.739 & 37.294 & & .583 & .561 \\
\hline & Work Environment & -.280 & 1.232 & -.309 & -.228 & .821 \\
\hline & Identification & .320 & .408 & .189 & .786 & .434 \\
\hline & Selection & .924 & .466 & .608 & 1.985 & .050 \\
\hline & Orientation & .440 & .214 & .196 & 2.060 & .042 \\
\hline & $\mathrm{X}^{*} \mathrm{LK}$ & .002 & .012 & .305 & .199 & .843 \\
\hline
\end{tabular}

3. Employee orientation sebelum dimoderasi oleh Work Environment memiliki nilai korelasi (Beta) dengan keterikatan karyawan sebesar 0.171, dan setelah dimoderasi oleh Work Environment nilai Beta tersebut meningkat menjadi 0.196. Dengan kata lain variabel Work Environment dapat memperkuat hubungan antara employee orientation dengan keterikatan karyawan. Hasil ini mencerminkan bahwa employee orientation yang merupakan sebuah keadaan internal yang dimiliki oleh karyawan, akan menambah rasa keterikatannya kepada perusahaan apabila Work Environment yang dirasakannya pun sudah kondusif.

Secara keseluruhan dapat dikatakan bahwa secara langsung, sistem rekrutmen, employee selection dan desain pekerjaan memiliki pengaruh dalam membentuk keterikatan karyawan, sedangkan employee orientation baru akan mampu meningkatkan keterikatan karyawan apabila dimoderasi atau diperkuat oleh faktor lingkungan tempatnya bekerja, dan tidak berpengaruh secara langsung dalam meningkatkan keterikatan karyawan.

Oleh karena itu untuk ke depannya pihak manajemen perlu memperhatikan Work Environment terutama dari beberapa indikator yang dianggap belum terlalu baik dirasakan oleh karyawan, seperti misalnya dari segi kebebasan yang diberikan karyawan dalam melaksanakan pekerjaannya, kemudian reward yang sebaiknya disesuaikan dengan penilaian kinerja karyawan, serta atasan yang bisa menjadi role model atau panutan bagi bawahannya.

\section{IMPLIKASI MANAJERIAL}

Berdasarkan pengamatan dan hasil wawancara dengan informan, serta pengolahan data secara kuantitatif, maka ada beberapa hal yang bisa menjadi cara untuk meningkatkan keterikatan karyawan di departemen claim health provider, antara lain:

Memberikan pengenalan atau orientasi kepada karyawan baru di departemen claim health provider mengenai visi dan misi perusahaan secara keseluruhan, keadaan lingkungan tempatnya bekerja, struktur organisasi, budaya perusahaan sampai dengan tujuan serta objektif departemen claim health provider ini sendiri.

Meningkatkan intensitas komunikasi dua arah, terutama yang berkaitan dengan masalah pekerjaan, antara head department sebagai atasan langsung, dengan bawahannya dalam rangka meningkatkan keterikatan karyawan terhadap perusahaan. Adanya komunikasi membuat 
seorang karyawan merasa dirinya dihargai dan diakui keberadaannya, sehingga ia akan lebih mudah untuk merasa terikat, terutama apabila karyawan tersebut diberikan kesempatan untuk menyampaikan apa yang ada di pikirannya.

Atasan langsung atau dalam hal ini head department memastikan agar karyawankaryawan yang menjadi bawahannya mendapatkan fasilitas-fasilitas yang dibutuhkan untuk dapat melaksanakan pekerjaannya secara maksimal. Fasilitas yang dimaksud, baik dalam bentuk fisik, maupun dalam bentuk informasi adalah beberapa hal yang diharapkan untuk ada, agar bisa dimanfaatkan oleh karyawan terutama di departemen claim health provider.

Pimpinan di lini tengah atau general manager bisa menciptakan sebuah kebijakan yang berisi ketetapan bahwa karyawan-karyawan baru harus mengikuti pendidikan dan pelatihan, terutama yang berkaitan dengn bidang kesehatan agar karyawan departemen claim health provider dapat lebih memahami detail pekerjaannya yang memang berkaitan dengan dunia kesehatan. Dalam kebijakan tersebut pun GM (General Manager) bahkan bisa memberikan kebebasan bagi karyawan itu sendiri untuk memilih pendidikan dan pelatihan tertentu bagi dirinya, selama benar-benar dianggap bisa meningkatkan kompetensi yang dimilikinya.

Sistem employee selection finansial yang ada saat ini bisa lebih ditingkatkan lagi dengan adanya kebijakan yang berisi pemberian insentif bagi karyawan departemen claim health provider yang mampu mengajukan klaim lebih banyak dibandingkan yang lain. Selain berupa finansial, pihak manajemen juga dapat menampilkan nama-nama karyawan yang termasuk dalam 10 besar terbaik di seluruh Indonesia, sehingga menjadi pemicu bagi karyawan lain agar bekerja lebih keras lagi supaya bisa menjadi 10 besar karyawan terbaik tersebut.

Perusahaan melalui manajer lini tengah, harus bisa mengembangkan manajemen performansi yang bisa membantu sistem akuntabilitas karyawannya. Caranya dengan melakukan survei secara rutin menggunakan kuesioner yang disebarkan melalui web internal, terutama berkaitan dengan keterikatan karyawan, serta faktor-faktor yang mempengaruhinya. Hal ini tentunya akan sangat membantu jajaran manajemen lini tengah untuk mengetahui faktorfaktor apa saja yang membuat karyawan merasa terikat dengan Perusahaan.

Secara strategis, jajaran direksi bisa mendorong kreativitas semua bawahannya 174 terutama dalam hal sistem dan cara kerja, dengan cara membuat semacam "kompetisi" yang diikuti oleh semua karyawan dari semua daerah. Kompetisi ini bertemakan mengenai inovasi seperti apa yang dimiliki oleh karyawan yang dapat mempercepat atau memotong durasi penyelesaian pekerjaan, dan bagi karyawan yang dianggap paling inovatif dan paling mungkin untuk segera diimplementasikan, maka akan mendapatkan hadiah baik dalam bentuk finansial maupun non-finansial.

\section{KESIMPULAN}

Berdasarkan hasil penelitian dan pembahasan yang sudah dipaparkan pada bab sebelumnya, maka sesuai dengan identifikasi masalah, dapat disimpulkan beberapa hal sebagai berikut:

1. Secara parsial dari dimensi-dimensi pada variabel bebas yang digunakan dalam penelitian ini yaitu sistem rekrutmen, position identification bukanlah subvariabel yang dapat dimoderasi atau diperkuat oleh kondisi Work Environment yang dirasakan oleh karyawan, sehingga dapat secara langsung memiliki dampak terhadap pembentukan keterikatan karyawan di sebuah perusahaan. Position identification yang tepat diasumsikan dapat membuat karyawan merasa terikat dengan tempatnya bekerja karena ia akan cenderung lebih cocok dan merasa nyaman dengan beban kerja sesuai dengan posisi yang ditempatinya.

2. Secara simultan atau bersama-sama, ketiga sub- variabel bebas yang digunakan dalam penelitian ini memiliki pengaruh yang signifikan terhadap pembentukan keterikatan karyawan. Sehingga dapat disimpulkan bahwa keterikatan seorang karyawan terhadap perusahaan tempatnya bekerja, dipengaruhi oleh variabel - variabel tertentu.

3. Variabel Work Environment disimpulkan tidak dapat menjadi variabel yang mendukung terbentuknya keterikatan karyawan oleh variabel bebasnya. Hal tersebut terlihat dari hasil analisis statistik dimana work Environment tidak terbukti sebagai variabel moderator antara variabel bebas (sistem rekrutmen) dengan variabel terikat (keterikatan karyawan). Oleh karena itu diperlukan adanya perbaikan-perbaikan dalam 
indikator Work Environment ini, agar pada akhirnya bisa menjadi pendorong terbentuknya keterikatan karyawan di departemen claim health provider.

\section{DAFTAR PUSTAKA}

Albdour, A.A. and Altarawneh, I.I. (2014). Employee engagement and organizational commitment: Evidence from Jordan. International Journal of Business, 19(2), p.192.

Baumruk R. and Gorman B. (2006). Why Managers Are Crucial To Increasing Engagement. Melcrum Publishing.

Ghozali, I. 2009. "Aplikasi Analisis Multivariate dengan Program SPSS. Semarang : UNDIP

Indrianti, N., (2012). An Exploratory Study Of Service Productivity Index For Service Industry Evaluation. International Journal of Services, Economics and Management, 4(4), pp.331-343.

Kaliannan, M. and Adjovu, S.N., (2014). Effective Employee Engagement and Organizational Success: A Case Study. Procedia-Social and Behavioral Sciences, 172, pp.161-168.

Komaruddin. (2007). Manajemen Kantor. Bandung: PT Trigenda Karya

Macey, W.H. and Schneider, B., 2008. The meaning of employee engagement. Industrial and organizational Psychology, 1(1), pp.330.

Mangkunegara, A. A. (2009). Manajemen Sumber Daya Manusia. Bandung: PT. Remaja Rosdakarya.

Markos, S. and Sridevi, M.S.( 2010). Employee engagement: The key to improving performance. International Journal of Business and Management,5(12), p.89.

Rana, S., Ardichvili, A. and Tkachenko, O.(2014). A theoretical model of the antecedents and outcomes of employee engagement: Dubin's method. Journal of Workplace Learning, 26(3/4), pp.249266.

Sedarmayanti. (2011). Manajemen Sumber Daya Manusia, Reformasi Birokrasi dan. Manajemen Pegawai Negeri Sipil (cetakan kelima). Penerbit: Refika Aditama.

Setiadi, N.J. dan Nalestiyas, A. P. (2014). Peran Keterikatan Karyawan dalam Memediasi Pengaruh antara Budaya Organisasi,
Gaya Kepemimpinan dan Loyalitas Karyawan pada PT Kantaraya Utama. Jurnal Bina Nusantara.

Sukirno, S. (2004). Makro Ekonomi Teori Pengantar. Jakarta: PT Raja Grafindo

Sugiyono. (2013). Metode Penelitian Kuantitatif, Kualitatif dan R\&D. Bandung: Alfabeta Supangat, A..(2006). Statistika Untuk Ekonomi dan Bisnis. Bandung: Pustaka. 
Jurnal Manajemen Maranatha — Vol. 16 Nomor 2, Mei (2017) 